\title{
Currency and Social Segregation, the Case of the Leper Colonies in Colombia
}

\section{Oscar Rodríguez Salazar and Décsi Arévalo Hernández}

\section{(2) OpenEdition \\ 12 Journals}

Electronic version

URL: http://journals.openedition.org/ei/6058

DOI: $10.4000 /$ ei.6058

ISSN: 2553-1891

Publisher

Association Économie et Institutions

Electronic reference

Oscar Rodríguez Salazar and Décsi Arévalo Hernández, «Currency and Social Segregation, the Case of the Leper Colonies in Colombia », Économie et institutions [Online], 26 | 2017, Online since 01 July 2018, connection on 30 April 2019. URL : http://journals.openedition.org/ei/6058 ; DOI : 10.4000/ ei.6058

This text was automatically generated on 30 April 2019.

Revue Économie et institutions 


\title{
Currency and Social Segregation, the Case of the Leper Colonies in Colombia
}

\author{
Oscar Rodríguez Salazar and Décsi Arévalo Hernández
}

\section{AUTHOR'S NOTE}

This article is the result of two research projects: "Currency and Social Protection Systems. The case of the Leper Colony of Agua de Dios in Colombia", financed by the Economic Sciences Faculty of the Universidad Nacional de Colombia, Bogotá campus, and "Currency and Social Protection Systems: the case of the leper colony of Contratación", financed by the office of the Vice-Rector for research of the Universidad de Los Andes, Bogotá.

\section{Introduction}

1 In Colombia, as in most of the Western world, a policy for leprosy arose which was guided by the aim of preventing society from being infected by a disease whose causes and adequate treatment were unknown in the field of medicine for a long time. Although the way in which society confronted this "disaster" varied over the centuries, a close relationship between the political regime, advances in the field of medicine which threw light on its causes and treatments and the financial-monetary policies of the country was evident.

In the case of Colombia, the fight against leprosy began during the Spanish colonial regime, a time when the first leper colonies were also founded. In the Republican period, especially during the Liberal governments of the mid- $19^{\text {th }}$ century, the State showed a stronger commitment to the problem by supporting leper colonies for the persons with the disease who could not afford to look after themselves. At the end of that century, 
under Conservative governments, the obligatory confinement of the diseased was decreed and barely at the start of the $20^{\text {th }}$ century a special currency was created for the leper colonies.

With the start of a new Liberal regime in the 1930's, there was a more flexible approach to the policy of confinement and the State decreed that the national currency should circulate in the leper colonies. In practice, however, the special currency of the colonies continued to be exclusively used within the colonies until they were closed in 1961.

The period chosen for this article combines two factors: the obligatory confinement of those with leprosy in the leper colonies and the introduction of a special currency for those places. These criteria define the period under study, which runs from 1890, when the law which established the obligatory isolation in Colombia of those with leprosy was passed, to 1930, the start of a change in public health policies which gave a greater flexibility to the confinement of those affected by the disease. In this period, there were three emissions of a special currency for the leper colonies in the country.

The convergence of these two occurrences: obligatory isolation and the issuance of a special currency for leper colonies was responsible for a case that might be considered as an "exceptional normal" ${ }^{1}$ one in the Colombian systems of social protection, insofar as we can find no other experience like it, but through it one may understand historical processes that were normal in the history of the country.

6 The exceptional normal nature of that situation turns out to be a suitable opportunity for reflecting on the idea of currency, understood as a social totality, since from that standpoint, one can analyze the links between two fields of research which have traditionally been separated: currency and social protection.

7 The case under study shows some features which allow us to enrich the discussion of some theoretical-methodological proposals, like those which regard systems of social protection as mechanisms of social mediation and those which deal with monetary sovereignty (Théret 2006 and 2013). The emphasis in the discussion is on two components: the idea of the State as an institution and the relations between the political, economic and domestic orders in the shaping of the system of social protection.

8 The sections which follow are arranged in the following way: the first discusses the way in which the obligatory confinement of diseased persons was established. The second discusses the relation between the special currency in leper colonies and the fiscal and monetary situation. The third deals with the special currency in leper colonies and the "monetary ration" for the living expenses of the interns. The final one presents our conclusions.

\section{Exclusion and social disaffiliation. Obligatory confinement}

9 As was mentioned in the previous paragraphs, when you look at the way the Colombian State set its policy for those who suffered from leprosy, it is possible to find a strong relationship between the political regime, medical knowledge and financial-currency rules in the Colombian experience. We need to point out that the definition of these policies incorporated long-lasting features insofar as there existed a culture of fear related to an illness which might infect a considerable percentage of the population and the way in which pre-capitalist societies conceived of poverty ${ }^{2}$. As follows, we discuss the 
manner in which that policy and medical knowledge were integrated to create and consolidate the obligatory confinement of the diseased.

When the colonial period ended, and closely following the principles of political liberalism in the territory of present-day Colombia, a democratic State with a separation of powers was established, adjusted to a system of laws, but with a citizenship of a patrimonial character. ${ }^{3}$ One of the challenges the Colombian State faced when imposing a new currency regime - which, in contrast with the one in force in the United States, which fixed the dollar as the new unit of account (Le Maux y Scialom 2013) - was to maintain the monetary rules implanted by the Spanish Crown, which was meant to give legitimacy to the new, independent country of Colombia (Rodríguez S. 2011a). Measures like the adoption of free trade, the abolition of slavery, the separation of the Church and State, federalism as a form of political organization, the disentailment of mortmain, the adoption of the gold standard and free banking were the programmatic axes of what was known as liberal radicalism (Rodríguez S. 2016).

11 Furthermore, liberalism introduced an analysis of responsibility - in the sense that Bourdieu uses it - about social problems: poverty was regarded more as the lack of dynamism in market forces ${ }^{4}$ than a matter of fate. What was known as the first Liberal Republic (1850-1886) issued a Charitable Code (Manuel Murillo Toro 1869), which was intended to "benefit, protect and assist poor or needy persons, without cost and without distinction". These roles, which were assigned to the Public Establishments of Charity and Beneficence, were the responsibility of the Federal States and the Municipal Corporations (Rodríguez S. 2006, p. 232).

Within this political framework, a system of social protection was designed, which organized the two most important leper colonies: in the town of Contratación (1861) and the town of Agua de Dios (1871). There was a third leper colony, Caño de Loro, founded in 1796, which had a small number of patients and was poorly financed, which was normal for the leper colonies a whole. During this early stage, those who had the disease were not forced to isolate themselves in these institutions and those who did could have access to the meager resources which the State devoted to dealing with the illness.

The path towards obligatory confinement began during the period of the Regeneration ${ }^{5}$ (1886-1903) and advanced during the government of General Rafael Reyes (1904-1909), who at the beginning of 1905 closed the Congress and summoned a Legislative Assembly with which he governed until the end of his term. During those 23 years measures were adopted which restricted both democratic freedoms and the exercise of political opposition, and the political agreements created in the Liberal period were radically changed.

This regime would be characterized by: political centralization, a State monopoly of the management of monetary supply, the centralization of revenues, the stabilization of the relation between Church and State, with its correlative of the ecclesiastical control of education, and the defense of national labor through a substantial increase in tariff levels which did not alter the terms of trade but did bring gains in the form of the political support of the artisan class. ${ }^{6}$

15 The Social Protection System implemented during this period was governed by the Church and the State. In 1886, as part of the process of political centralization, a Central Hygiene Board was organized which supervised the departmental boards, some of which were responsible for public health measures and also for anti-leprosy campaigns. 

Charity of the Presentation of the Blessed Virgin) sought to gain social, political and cultural legitimacy by overestimating the number of the diseased. Among those who promoted the idea that "Colombia was the world leader in leprosy" (Martínez 2006) was the Salesian Father Evasio Rabagliati, who arrived in Colombia in 1890 and later held the posts of "Visitor to the leper colonies" and "Chaplain of the country's leper colonies", and was known in his day as the Apostle of the Lepers (Ortega 1938). In a talk given on August 2,1896 , this priest "spoke of the increase in the number of those with the disease from 27,600 to 40,000 and even 50,000 in a single year" (Cuellar 2014, p. 23) ${ }^{7}$. In the face of such a calculation of the number of the diseased, their obligatory confinement was shown to be unavoidable.

21 For his part, General Reyes stated that "there are 27,250 people with elephantiasis in Colombia, more than in the rest of America and Europe". With the aim of fighting that scourge, he called on a group of citizens to form a board, in association with Father Rabagliati, and "with the resolute and enthusiastic collaboration of the clergy and the country's charitable organizations", collect funds for the founding of a National Leper Colony (Martínez 2006, p. 66).

These inflated figures enabled Rabagliati to go ahead with his original proposal to create "Lepers Banks" in the major cities, with the aim of organizing departmental lepers' colonies. The funds from public charities would be converted into shares in the bank ${ }^{8}$. In 
Bogotá, the bank founded in 1901 amassed a capital of $\$ 150,000$ pesos in only three months. Two years later, a similar one was created in the city of Tunja ${ }^{9}$, which had an initial capital of $\$ 31,045$ gold pesos, the equivalent of 6,209 shares worth $\$ 5$ pesos each. Two years after that, that organization became the Banco de Boyacá and its philanthropic aims were forgotten (Martínez 2006, p. 93).

By exaggerating the number of the diseased, both the medical community and the Salesian Order led General Reyes to regard leprosy "as the most important problem the country had, more than paper money, railways and public education" and only comparable with peace. In 1904 Reyes sent an urgent circular to the Congress with the aim of "eradicating leprosy" by isolating the patients, in which he agreed with Doctor Sauton's over-estimate of the number of lepers in the country (Martínez 2006, p. 183).

This inflation of the problem had repercussions in foreign markets. The press in the United States published articles about the disaster Colombia was suffering and the effects were seen in the restrictions which were imposed on Colombian exports, especially coffee.

With that diagnosis, the government decided it was imperative to adopt administrative measures aimed at controlling the disease. It established the Central office of Leper Colonies, under the Ministry of Government, which was charged with the direction and administration of the colonies in Colombia, formerly run by charitable boards, religious orders and public charities.

In the case of the most important leper colony at the beginning of the 20th century, located in the town of Agua de Dios, the government of the Department of Cundinamarca (where it was situated), issued Departmental Decree 159 of 1907, which divided the administration of the leper colony into an external and internal part (Art. 1). The policing measures laid down in article 41 gave the inspector of police the responsibility for: supervising on his part and those of his subalterns the enclosures of isolation and reporting the damages seen in them to the Administrator; and preventing any act which tends to destroy the enclosures of isolation or render them ineffective".

Article 55, which dealt with disinfection, prescribed that "in the office of the marketplace there will be a place responsible for disinfecting the official and private correspondence which leaves the leper colony". Article 58 stipulated that "all of the healthy persons who reside in the leper colony, regardless of the position they hold, must supply themselves with disinfected clothing when they need to leave it" ${ }^{10}$.

The Social Protection System developed during the Conservative Republic was based on the use of charity and hygiene as a device of social control (Noguera 1998). It adopted the standpoint of Christian charity and can be characterized as what Bruno Lautier (1999) calls "repressive" aid. The social protection applied in the leper colonies did not achieve much, according the report the Central Board of Hygiene ${ }^{11}$ submitted to the Congress in August, 1915, which stated that:

[...] the foundation of the Lepers Colonies has a twin aim: the protection of the diseased, lightening the burden of their enormous affliction, and social defense, to prevent the spreading of this terrible disease by all means recommended by science. Despite the goodwill of the government and the large expenditure the country makes on supporting the lepers colonies, the victims of the disease are not well cared for nor is society effectively protected (Board of Hygiene 1915, p. 71). 


\section{The special currency for the leper colonies and the fiscal-monetary problems} as a matter of obligation, as a legal tender there. In the words of decree 129 of 1900 , "it was an urgent matter of policing and hygiene that the dangers implied by the circulation of national bank notes in the leper colonies be eliminated whenever possible", dangers which could be reduced with the circulation of the metallic currency. To implement that stipulation, the government issued decree 300 of 1901, which defined the characteristic of the special currency for the leper colonies:

- Denominations: 50, 20, 10, 5 and 21/2 centavos;

- Metal: alloy of aluminum and copper ${ }^{15}$;

- Size: equivalent to those of the silver coins with a 0.835 silver content

- which circulated on a national level, with their respective denominations;

- Design: on one side there is a Maltese cross with the word leper colony in the center and the value is written in letters around it. The other side specifies the value in numbers and the legend "Republic of Colombia" is written around it. 


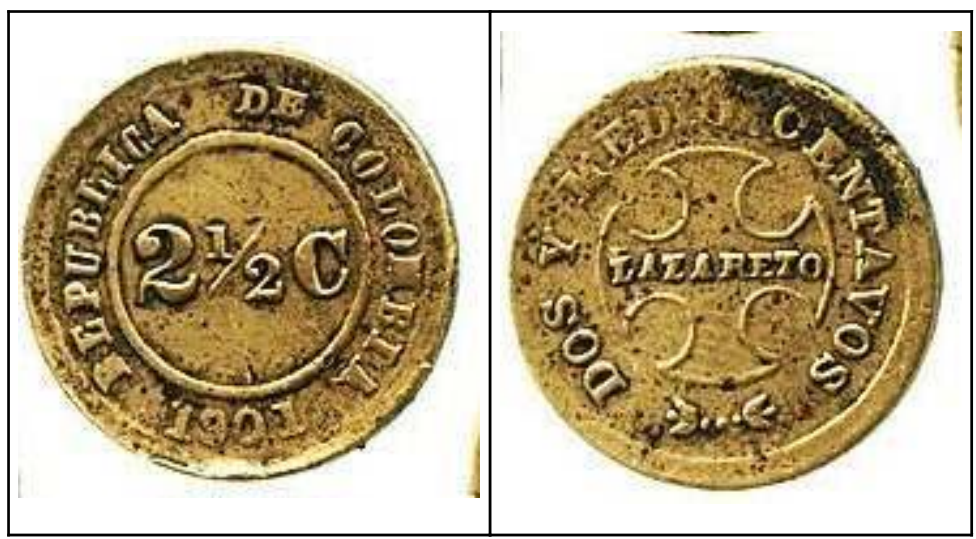

Source:http://media.liveauctiongroup.net/i/11661/12160176_1.jpg?v=8CECC6A244EEAD0

These characteristics of the special coins for the leper colonies show the intention to maintain a direct reference to the national currency insofar as they maintained the same sizes and denominations, but expressed a symbolic message of stigmatization. Furthermore, this emission showed that in the thinking of the legislator there was the idea of a limited need for exchange, since the volume of the transactions that could be made with those denominations was restricted.

When the War of a Thousand Days ended, a process of monetary reorganization began that turned out to be rather slow ${ }^{12}$. Two of the main problems with monetary affairs the country faced were, on the one hand, a shortage of minerals to mint coins with and a return to the gold standard, as the reforms of 1903, 1905 and 1907 promised, and, on the other, the absence of a bank of issue.

The monetary system which resulted from those reforms was the bimetallic standard of gold and silver in a fixed ratio of $1 / 33$ (each gram of gold at 0.900 corresponded to 33 grams of silver with the same content) but with limits on both the amount of silver coins (their mintage could not surpass $10 \%$ of the mintage of gold coins) and the purchasing power of silver coins (no more than 10 pesos in any transaction). Similar rules applied to the fractional coins in nickel and copper ${ }^{17}$. For a long time by then and despite promises to return to metallic currency, paper currency continued to circulate (both those issued by the now defunct Banco Nacional and the currency emitted to finance the war).

Even after agencies were created which were supposed to collect the banknotes and reconvert them into metallic currency, not enough metal was available nor were there adequate financial resources to administer the change. The monetary problems of the country were aggravated, in the first place, by the absence of a bank of emission ${ }^{13}$ or central bank, and in the second place, by the constitutional reform of 1910 which prohibited the emission of paper money as legal tender.

In the midst of the abovementioned reforms, and in line with Law 8 of 1905 of the Constitutional Assembly and a strengthening of the policy of confinement, the government ordered the minting of a new series of special coinage for the leper colonies (formalized by decree 1452 of 1907, when the perimeters of the leper colony at Agua de Dios had been fully enclosed in barbed wire), which corresponded to 30,000 gold pesos in nickel coins of 1, 5 and 10 centavos. This feature of the coinage was the reason why the 
special coins for the leper colonies became known as coscoja, meaning "a little thing", that is, coins of little value.

39 In 1915, arguing that the amount of currency issued for the leper colonies was insufficient, the government decided to increase its minting of copper-nickel coins at a total amount equivalent to $\$ 21,026.70$ gold pesos. The peculiarity of this emission is that it corresponded to a monetary reform of that currency, since the face values of the coins were modified to take inflation into account.

In the former emissions, the coin with the highest value was the gold 10 centavos one and now denominations of $50,20,10,5$ and $2 \frac{1}{2}$ centavos were minted. They were meant to replace all of the coins minted in 1901 (which, in fact, was the date on the new coins). As in previous decrees, the circulation of the special currency beyond the limits of the leper colonies was prohibited and the penalty was the seizure of the money. This strategy of monetary reconversion also served as a form of financing the spending on that institution. However, given the difficult fiscal conditions of the country, the emission was not undertaken.

41 Decree 2209 of 1918 once again called attention to the need to remit money to the leper colonies and in this case, referred not only to the shortage of the special currency but directly mentioned the financial needs in question, since this currency was meant to pay for the monetary rations of the patients. But, given the abovementioned fiscal crisis and the measures adopted since 1915 to transfer the funds in the possession of the Conversion Board (meant for the exchange of paper money) to the "common funds" of the General Treasury, there was no way to finance the new mintage.

The authorization to mint new coins in 1918 came into play three years later when the country faced a new economic crisis and the government a new fiscal one. Decree 738 of 1921 ordered the minting of $\$ 100,000$ pesos in denominations of $50,20,10,5$ and 1 centavos. The implementation of the reform thus authorized was meant to be gradual, depending on the resources available to the Conversion Board, insofar as the Conversion Board would mint the new coins in stages and step by step, send them to the General Treasury so that it could pay the rations with them. The coins were also meant to replace the nickel and copper coins which were in circulation. The last minting of the coscoja took place in 1928 , but it was only in the form of bronze coins of $\$ 0.50$ pesos.

There were major difficulties on the fiscal front. In addition to the debt the State had incurred in to finance the War of a Thousand Days, revenues from customs duties had significantly fallen, triggered, in turn, by the fall in the price of coffee, the main export product. The slow economic recovery which started to take place in 1910 was then halted by the negative effects of the First World War and forced the country into a severe fiscal crisis. As we have said, the fall in fiscal revenues could not be made up for with the emission of more currency.

As the Treasury Minister, Esteban Jaramillo, pointed out in his report to the Congress in 1918, from the end of 1917 there had been an uninterrupted fall in State revenues which increased the fiscal deficit, which by the end of July 1918 had risen to nearly $40 \%$ of the budget for that year (Jaramillo 1988a, p. 59). According to that Minister, the financial problem was caused by a fall in customs revenues (which was the main source of government income), due to the closing of imports by the War.

In his opinion, so long as the conflict was restricted to the countries of Europe, the level of Colombian imports was maintained, but when the United States, Colombia's main trade 
partner, joined in the war, the fall in imports dealt a harsh blow to customs revenues (Jaramillo 1988a, p. 59). Given that situation, the government dismissed the possibility that an increase in taxes would bring about higher government revenues, since, in addition to the expected opposition to such a measure, the tax would fall on consumer products and thus might reduce consumption or stimulate the trade in contraband goods (Jaramillo 1998b, p. 235) ${ }^{14}$.

To this temporary situation there was added a longer-term problem: the State's weak capacity to emit currency, which thwarted the possibility of using currency as a fiscal resource. In the first place, the country did not have a bank of emission ${ }^{15}$ and in the second, the constitutional reform of 1910 prohibited emissions of legal tender and the government did not have the resources to back the emission of paper money with metal, nor a sufficient capacity to coin metal ones.

Since it was impossible to raise taxes or use emission as a source of State funding, there was a dependence on credit whenever there was a crisis. Of course, the situation was not novel: throughout nearly the whole of the $19^{\text {th }}$ century, indebtedness had been the characteristic of public finances. The worrying aspect of the situation was that, due to the war, external credit was practically blocked and there was no other alternative but to negotiate domestic credit, when, as had happened in other critical times in the history of the country, the potential lenders were reluctant to meet the needs of the government.

The efforts of the Treasury Minister, Pedro Blanco (1917-1918), to obtain credits from the bankers had meager results. The head of one of the country's biggest banks (the Banco de Colombia) suggested that one solution to the monetary crisis would be to revoke the norm which prohibited mortgage banks from issuing mortgage bonds at a value of less than one hundred pesos, originally intended to prevent such certificates of value from being used as a currency or paper money.

After the meeting between Minister Blanco and the bankers, the government issued decree 319 of 1918 which allowed the banks to emit mortgage bonds of any value again. The banks responded to this measure by granting the government a short-term loan of $\$ 580,000$ pesos, partly in currency and partly in mortgage bonds which the government put into circulation as currency, at an $12 \%$ interest rate and backed by the revenues from the salt exploitations it ran (Blanco 1918). With a deficit of nearly 5 million pesos, the credit was soon exhausted, especially by the payment of debt.

As an alternative means of finance, the Congress authorized an emission of bearer bonds (Law 23 of 1918), with an annual interest rate of $10 \%$, bills payable on demand, with a three-month term and redeemable on a weekly basis through a lottery and backed by all of the government's revenues. The results were not favorable, because, in the opinion of Minister Jaramillo, the resources were not only inadequate but they were also used by people to pay urgent cash debts, so they sold the bonds at a high discount. In addition, the format of the notes did not inspire enough confidence, there was not enough currency for people to acquire them and money exchangers charged a high commission (Jaramillo 1988a, p. 64-65).

In 1919, the new Minister managed to obtain loans of $\$ 1,694,500$ pesos, that is, thrice what Minister Blanco had secured from the bankers, but the loans took the form of bills of exchange and drafts on foreign banks, which the government could not introduce to the domestic market because that would cause a strong devaluation. Using a creative device, the government exchanged those notes for English bank notes in foreign markets 
and used the Sterling to pay for its domestic purchases until the Supreme Court ruled that the measure was unconstitutional. That led to a threat of a further crisis, which was solved with its promise to redeem the bank notes in the hands of the public at a rate at par with the national currency (Jaramillo 1988b).

Two other factors aggravated the situation. On the one hand, the traditional deficit in the balance of trade with the United States gave way to a position of surplus which could not be taken advantage of because in that period the United States did not allow the export of metallic currency. On the other, the export of gold, both in coins and ingots, was permitted and once again, the financial position of the government did not provide it with the resources to prohibit it and acquire the gold.

The effects of the financial crisis were enormous and a collateral effect was that the policy to control the lepers was threatened, as was stopping the spread of Hansen's disease in the end. There were further collateral effects, noted by Minister Jaramillo:

Thus, in the month of December [1918], a very grave situation arose, since evident symptoms of decomposition and disaster were noted in several branches of the public administration: the exodus of the diseased persons from the refuge of the leper colonies because their rations had not been paid; visible symptoms of discontent in some units of the army; attempts to refuse to do their work on the part of some units of the police; strikes by the employees of the judiciary in different places and everywhere, vehement and prolonged complaints and expressions of protest about that situation, which had become unsustainable (Jaramillo 1998a, p. 67).

That situation was not unknown in the country: a good number of the deficits in the $19^{\text {th }}$ century and early $20^{\text {th }}$ century had resulted in the postponement of the payment of the salaries of public officials and a failure to comply with the commitments of social protection.

This difficult financial situation had a strong impact on the leper colonies, since the mortuary tax had provided very few revenues and as a result, the shortfall had to be financed from the national budget. At the same time that the isolation of the diseased was legally authorized, a source of finance was established for the maintenance of the sites of reclusion: the leper colonies tax. In the process of centralizing the management of the leper colonies (1907), this tax, collected in every department of the country, was intended to be the main source of financing the government needed to attend to the needs of the functioning of those colonies, which included the development of the physical infrastructure, the administration of their operations, medical care and support for the living expenses of the diseased.

For the financial year of 1918 the tax on mortuaries had yielded $\$ 150,992.50$ pesos and total expenses rose to $\$ 571,553.49$ pesos, that is, the tax barely covered $28 \%$ of total expenses. The shortage of resources is a common theme in the different reports of the Board: year after year, it repeated that it was impossible to fulfill the plans for improving the infrastructure, supplies and medical equipment in the colonies, due to a lack of sufficient resources. From the figures shown in the previous table, it is clear that the monetary ration given to each patient amounted to an average of $\$ 0.22$ pesos, well below the amount stipulated in the legislation of that period ( $\$ 0.30$ pesos).

A report by the Central Hygiene Board in 1916 detailed the expenses of the leper colonies for the period between June 1,1915 and July 1, 1916. 
Table 1. Annual Expense of the leper colonies, 1915/1916

\begin{tabular}{|l|l|l|l|}
\hline Item & $\begin{array}{l}\text { Agua de } \\
\text { Dios }\end{array}$ & Contratación & $\begin{array}{l}\text { Caño } \\
\text { Loro }\end{array}$ \\
\hline Patients & 2,458 & 2,069 & 149 \\
\hline Male patients & 1,226 & 1,092 & \\
\hline Female patients & 1,232 & 977 & \\
\hline Rations of the patients & & & $17,510.90$ \\
\hline Salaries of all the employees & $203,762.07$ & $172,215.91$ & $12,167.25$ \\
\hline Buildings and maintenance & $37,157.00$ & $27,213.05$ & $8,192.42$ \\
\hline Leasing of locales for the patients in the leper & $13,036.00$ & $2,137.00$ & 209.50 \\
\hline colonies & $16,387.20$ & $7,844.5$ & $\$, 080.00$ \\
\hline Maintenance of the healthy children of the lepers & $14,700.79$ & $5,618.07$ & 0.00 \\
\hline Domestic services in the hospitals and asylums & $12,356.50$ & $9,120.00$ & $4,811.00$ \\
\hline Discounting the ration, each patient has cost & $\$ 8.79$ & $\$ 8.51$ & $\$ 2,220.00$ \\
\hline
\end{tabular}

SOURCE: ON THE BASE OF JUNTA CENTRAL DE HIgIENE (1916)

Given the financial conditions at the time, the General Treasury transferred the remittances to the treasuries of the leper colonies in different kinds of currency; that is, it depended on the currency which was available to it at the time. It included gold-backed bank notes (made by the American Bank Note Company), bank notes from the defunct Banco Nacional, resealed bank notes (from the time of the War of a Thousand Days), the national currency and the special coins for the leper colonies. In addition, the transferences of the government were sporadic, one of the factors responsible for the financial crisis in the colonies. It was not until 1928, under the last president of the Conservative Republic, Miguel Abadía Méndez (1926-1930) that the government decided that the remittances to the leper colonies should exclusively be in metallic currency (decree 831 of 1928). 


\section{The monetary ration: central component of the institutional design}

The special currency has to be jointly analyzed with the ration as two components employed to carry out the policy for the leper colonies, which sought to ensure that the diseased remained in those places of reclusion.

For the maintenance of those interned in the leper colonies, a "ration" was established ${ }^{16}$, in the form of a daily monetary payment for each one. And it was understood to be a mechanism to ensure that the leper would stay in the place of confinement on the supposition that he or she would be supplied with the means needed for his or her physical maintenance there. A difference was established between the amount of the ration for the lepers who were hospitalized and the amount for those who were not. The latter received more, on the grounds that the hospitalized lepers were already being subsidized, to a degree, by the sanatorium in which they were being treated.

61 The policy for the obligatory confinement of the diseased persons caused a major pressure on governmental finances which could not be eased by the mortuary tax or the transferences from the national budget. Although there were many provisions adopted to increase the yields from and improve the administration of the tax, the shortage of resources was seen in delays in the infrastructure work, failures to pay the officials on time and reductions of the ration. The cuts in the last item began pretty quickly. In 1910 (under Decree 300 of that year), it was decreed that the isolated patients who enjoyed an income or revenue which allowed them to support themselves and the patients who were employees of the colonies and had monthly income of more than 30 pesos would only be entitled to a daily ration of 10 centavos (3 pesos a month); that is, half of what the other lepers received. For their part, the interns in the hospital of the leper colony would receive: 0.15 percent of a peso in food, laundry expenses, clothing, etc., and $\$ 0.05$ pesos in money.

According to the legal norms, the ration was to be given to the patients on a weekly basis, that is, on one day they would receive enough to cover their expenses for a week. Once it was handed over, the ration was used buy food in the local marketplace, since nothing was grown in the colonies and anything in the way of manufactures or commerce was very limited and restricted to relatives of the patients or people who lived in the same community but in a separate section ${ }^{17}$.

63 The patients paid the traders they bought from with the special currency and those traders had to remit the coins to a treasurer who suffered from the disease, who, in turn, gave them a promissory note which was meant to be redeemed by the official treasurer of the colony, who was free of the disease, and when the money was available, paid the traders with national coins or banknotes. When it was not, he gave them a postal order which they could redeem in banks, with the payments backed by the General Treasury of the Republic.

The patients who had to engage in transactions with those who lived outside of the leper colonies had to follow a similar procedure: they were required to solicit a postal order - the only manner in which they could undertake such transactions - and hope that there was enough money in the treasury of the colony. The money in the treasury came from government transferences and there was an order that the priority for the exchange of 
currency should be: first, the food suppliers and then the inmates, in accordance with their place on the line and the availability of the money.

In a setup of that nature, it was not surprising, as different reports in that period noted, that the interns became victims of usurers. The report which the Central Board of Hygiene submitted to the Congress in 1916 estimated that due to rises in the price of foods, the ration had lost $30 \%$ of its value. In addition, the difficulty of exchanging the special currency for money or postal orders for external transactions was exploited by money-lenders.

The obligatory use of a special coinage of little value issued in insufficient amounts, like the granting of a meager ration and the delays in receiving it, meant that the population of lepers and others in the leper colonies assumed the costs when the nominal value of the funds assigned to them were reduced by cuts in the daily ration and coins of little value. The combination of these two factors fed into an economy of credit which increased the cost of living for those in the leper colonies.

The special currency which circulated in the leper colonies should be regarded as an extension of the way in which the State, in the exercise of its sovereignty, instituted a special monetary regime for the places where the lepers were confined due to a disease which, given the limited medical knowledge at that time, was considered as potentially dangerous for society. The argument that the disease was only transmitted by paper money, not coins, was an effective defense of a fractional currency.

However, the main purpose of that currency in the leper colonies was to secure the confinement of the diseased as a way to prevent them from infecting the rest of society. Thus, the community of payments which was established with that unit of account had to fulfill the function of stopping the diseased from going beyond the geographical limits of the colony, that is, it exercised a social control over those with Hansen's disease.

69 That situation means that we have to regard the special currency as more than a monetary instrument and think of it as part of both the monetary regime and the system of social protection. If only its instrument nature is taken into account, it can be thought of as a parallel currency (Blanc 1988), like many others which existed in the country, that is, it was not its distinguishing feature. As was mentioned above, during the War of a Thousand Days, the government resorted to any monetary species it could lay its hands on, including private coins issued by businessmen for the convenience of their consumers (or commercial intermediaries). Another important example of parallel currencies were the hacienda coins, which had different shapes, values and units. Some were made of wood of leather and their unit of measurement might be a day of work or a ration of food, others could be a vile metal and have as the unit the same as the national currency.

Like the special currency for the lepers' colonies in its condition of a monetary instrument, these parallel currencies could serve such functions as payment, credit and value deposits, even though the area of their circulation was limited. The differences between them had to do with the political, socio-economic and monetary system in which they were inscribed. The contrast between the special currency of the lepers' colonies and the tokens illustrate the point. The latter were used by the owners of haciendas to pay for the work of their peons and they were redeemed through the purchase of goods sold in the stores on the estate run by the landowner and later, circulated again when the workers were paid, so that their commercial value was wholly governed by the emitter, since he alone controlled the two ends of the procedure. 
71 By contrast, it was the State which issued the special lepers' currency, which was defined in accordance with the national currency unit so that the referent of sovereignty was the State and its value was affected by the factors which affected the national currency. Furthermore, the amount of money in circulation depended on the size of the transferences from the State, especially for the payment of lepers who were government employees and the monetary ration.

72 As indicated above in the case of the ration, the cycle is: a) weekly payment of the ration in special currency to the lepers, b) transfer of the special currency to the merchants who come from outside the leper colony through the purchase of merchandise, c) exchange of the special currency that the merchants received from the leper-buyers for a voucher in the internal treasury of the leper colony and, d) finally, exchange of the voucher for national currency in the external treasury of the leper colony.

This cycle meant that if previously the external treasury had not made the appropriation for the conversion of the vouchers into the hands of merchants by national currency, the monetary circuit was broken. When the external treasury does not have national currency to make the change of the vouchers, it did not pay the monetary ration, consequently the circuit cannot be started. In contrast whit the hacienda coins the special currency was not able to function unless there was previous deposit of resources in the national currency that would pay for the merchandise.

That situation was not only owed to the financial straits of the national government, but also to the fact that, from the standpoint of the State, the ration was not a payment for a job of work or the provision of a service, but a subsidy, that is, the State did not acknowledge that it a was social debt owed to the lepers. By the same token, the cycle of payments and purchases was not confined to the area of the leper colony but depended on economic activities which took place outside of the colony.

Under this condition an interruption in the payment of the ration induces to limit the consumption and / or to increase the credit. The monetary circuit created by the ration does not translate into the total absence of special currency in circulation. On the one hand, not all special currency is used for purchases from merchants outside the leper colony, but also for internal purchases; on the other, the payment of the lepers who work as government employees also generates a special currency flow.

76 The effects of the currency will depend on the condition of income and health of the leper, those who do not have means of living will be more exposed to the abuse of credit, than those who develop some economic activity. All this was the consequence of a system of social protection based on the confinement of the lepers, since they did not have the resources needed to produce the goods and services which their subsistence depended on.

77 Finally, it should be added that in the stricto sensu the special currency did not translate into a good hygiene practice, since the merchants outside the leper colony came into direct contact with the patients and with the "coscoja", and this did not mean a significant increase in contagion.

\section{Conclusions}

78 This analysis of the currency in the leper colonies questions the standard approaches to the study of currencies. The categories found in such research programs cannot provide 
answers to the question of the role played by currency in a society of the excluded. We can barely begin to analyze that question on the basis of a number of economic concepts (unit of account, means of exchange and store of value) which are limited and whose application is neutral in the case of social groups and with regard to the economy ${ }^{18}$.

An alternative tool of analysis related to this "exceptional normal" occurrence is one based on a program of investigation which acknowledges that the currency rests of three foundations: debt, trust and sovereignty, which is more of a social relationship than an economic instrument, forms an integral part of the political system and is guaranteed not by the mercantile system but the law. In this sense, it would behave like a social contract, that is, the legitimacy of the currency is purely political, since it perennially links the individual with society as a whole (Aglietta 2016).

Thus, the choice of a monetary regime is a political option, since the currency is not the result of the mercantile economy, but, on the contrary, the currency establishes the mercantile economy. The result of an approach of this kind is to do away with "the neoclassical fable which holds that the increase in transaction costs associated with barter might have led the economic agents, on their own, to invent currency" (Boyer 2015, p. 34).

81 The coscoja functioned within a monetary area whose limits were defined by the perimeters of the leper colony, imposed on its inhabitants, who, to use the term of Castel (1997), were placed in a condition of social disaffiliation. This enclosure not only sought to prevent the disease from spreading but also to limit the possibility that those with Hansen's disease might leave the "city/prison" whose borders were defined by a barbed wire fence and guarded by squads of policemen.

We should recall that the obligation to accept a currency imposed by the government is not an exceptional case in the monetary history of the current nation of Colombia. The antecedents go back to the Spanish empire, which implanted its currency during the colonization of America. Another example was the imposition of a legal tender during the period of the Regeneration, which had been preceded by the acceptance of the paper money of the Banco Nacional in the offices of the Ministry of Finance as a form of the payment of taxes. The same would apply to the different monetary resources the government resorted to during the War of a Thousand Days.

In the case of the coscoja, the imposition of a currency was an exercise of political sovereignty, based on the idea that it was a way for the State to protect another sector of the population and thus guarantee its survival. At the start of the enclosure of the leper colonies, the constitutional order which the State legitimized was regarded as a repressive measure in the sense that it was illegitimate for those who were confined, which, in turn, called into question the sovereignty of the political power, a doubt which grew when the patients who were the victims of it were stripped of their political rights, and lost their status as citizens for a long time.

This loss of citizenship, as well as the way it placed the victims on the margins of a salaried economy, meant that they were not compensated for the payment of the social debt which applies in salaried societies and in the context of Welfare States - but that their social protection resided in a charitable -repressive policy managed by the State, private entities and the Church. One of the main ways to secure its application was the "monetary ration", a sort of subsidy on demand, on the condition that they remained in the ghetto. 

political regimes. During the period of the Radical Olympus (the first Liberal Republic), while it did include the founding of three leper colonies, the treatment of the diseased did not stipulate their obligatory confinement. In the Conservative Republic, particularly in the period between the Regeneration and the dictatorship of general Reyes, the policies 
became more repressive. Finally, with the development of the process of industrialization, urbanization and a salaried economy, accompanied by a political regime that was a little more democratic, known as the second Liberal Republic, the policies of confinement became more flexible.

The way in which the political regime acted towards the diseased was also articulated to changes in the administrative field. Insofar as the design of the policy was charitable/ repressive, the Ministry of Government was the agency responsible for implementing it. Insofar as it was a policy for the prevention of the disease, it was the Ministry of Public Education. Insofar as leprosy was regarded as a disease which incapacitated those who suffered from it, the responsible agency was the Ministry of Labor and Social Care ${ }^{19}$. Of course, such changes also interacted with the dynamics of both the Colombian and international scientific community.

The lack of knowledge about the way in which the disease spread led to the design of "inhuman" policies against those who suffered from it. The 1897 Berlin Congress legitimized the policy of isolation. For its part, the $6^{\text {th }}$ Pan-American Conference (1928) which established the Pan-American Sanitary Code changed that policy in the sense that leprosy was no longer regarded as a sanitary problem but a question of public health.

While they did not respond to the dynamics of the dependent countries themselves, these changes corresponded to transformations in the accumulative and political regimes of the countries of the center. Among the trends which modified the social order there was the development of the salaried relationship, which imposed the payment of social debts as one of its criteria: that of social progress. The problem of responsibility is associated with this idea, as Bourdieu rightly notes:

The discovery of the microbe favors the collectivization of the risk. If microbes exist, then individuals are not responsible for their own diseases. In the period when the microbe was discovered, it was an argument for the socialization of the risks and the removal of individual responsibilities within the social sphere - it is possible to find an analogy with the genetics of today. (Bourdieu 2012, p. 574).

Social progress not only gave a priority to the payment of the social debt in the face of private ones, but it recognized that a fundamental condition of attaining a better quality of life was to have a healthy population but with due respect for their human rights, which did not happen with the social disaffiliation of those who suffered from the bacillus of Hansen.

\section{BIBLIOGRAPHY}

Acuña O. (2014), « Aproximaciones a la historia empresarial de Boyacá (Colombia), 1900-1930 », Historelo, 6(12), p. 425-443.

Agudelo C. \& C. Plata-Rueda (2004), Ensayo de una bibliografía sobre la lepra y lazaretos en Colombia 1535-1871. Prácticas y relaciones sociales, Tesis de pregrado en historia y Antropología, Bogotá, Universidad Nacional de Colombia. 
Aglietta M. (2016), La Monnaie entre dettes et souveraineté, Paris, Odile Jacob.

Aglietta M. (1992), « Genèse des banques centrales et légitimité de la monnaie », Annales. Économies, Sociétés, Civilisations, 47(3), p. 675-698.

Arévalo D. (2016), « Gran especulación. Política y moneda en la guerra de los mil días », in D. Arévalo (ed.), Soberanía política y regímenes monetarios, Bogotá, Universidad Nacional de Colombia, p. 125-171.

Blanc J. (1998), « Les monnaies parallèles : évaluation et enjeux théoriques du phénomène », Revue d'économie financière, 49, p. 81-102

Blanco P. (1918), Memoria del Ministro del Tesoro al Congreso Nacional de 1918, Bogotá, Imprenta Nacional.

Bizberg I. (2015), « Tipos de capitalismo y sistemas de protección social », in I. Bizberg (coord.), Variedades de capitalismo en América Latina: los casos de México, Brasil, Argentina y Chile, México, El Colegio de México, p. 285-343.

Botero N. (2009), Nos hicimos a pulso. Memoria de os hijos de enfermos de lepra, en el Lazareto de Contratación Santander, Tesis de pregrado en Sociología, Bogotá, Universidad Nacional de Colombia.

Boyer R. (2015), Économie politique des capitalismes. Théorie de la régulation et des crises, Paris, La Découverte.

Bourdieu P. (2012), Sur L'État. Cours au Collège de France 1989-1992, Paris, Le Seuil.

Castel R. (1997), La Metamorfosis de la cuestión social. Una crónica del salariado, Buenos Aires Barcelona, Paidós.

Coni E. (1921), La higiene pública y la organización sanitaria en Colombia. Bogotá, Minerva. En ligne: http://www.banrepcultural.org/sites/default/files/88665/brblaa579824.pdf

Cruz P. (1946), La Sanidad en Colombia. Extracto de la Memoria del Ministerio de Higiene para el año 1946. En ligne: http://iris.paho.org/xmlui/bitstream/handle/123456789/14255/v27n9p806.pdf? sequence $=1$

Cuellar F. (2014), Medicar desde Bogotá. Estudio de la consolidación de la medicina y el tratamiento de la lepra en Colombia 1874-1905, Monografía de Grado, Bogotá, Universidad de Los Andes.

Gardeta P. (1999), « Discurso sobre una enfermedad social: La lepra en el Virreinato de Nueva Granada en la transición de los siglos XVIII y XIX », Dynamis: Acta Hispanica ad Medicinae Scientiarumque Historiam Illustrandam, 19, p. 401-428.

Ginzburg C. (1994), « Microstoria: due o tre cose che so di lei », Quaderni Storici, 86, p. 511-539.

González F. (2006), Partidos, guerras e Iglesia en la construcción del Estado nación en Colombia, Medellín, La Carreta.

Guillen F. (1986), La Regeneración, primer frente nacional, Bogotá, Valencia Editores.

Jaramillo E. (1988a), « Memoria del Tesoro de 1919 », in Cámara de Representantes, Esteban Jaramillo estudios y antología, Tomo II, Bogotá, Cámara de Represent antes, p. 58-93.

Jaramillo E. (1988b), « Estudio sobre asuntos monetarios y fiscales », in Cámara de Representantes, Esteban Jaramillo estudios y antología, Tomo I, Bogotá, Cámara de Representantes, p. 223-236.

Junta Central de Higiene (1915), Exposición de la Junta al Congreso Nacional de 1915, Bogotá, Imprenta y litografía de J. Casín. 
Junta Central de Higiene (1916). Exposición de la Junta al Congreso Nacional de 1916, Bogotá, Imprenta y litografía de J. Casín.

Lautier B. (2006), « Las condiciones políticas para la universalización de la protección social en América Latina ", in Y. Le Bonniec \& O. Rodríguez-Salazar (ed.), Crecimiento equidad y ciudadanía. Hacia un nuevo sistema de protección social, Bogotá, CID - Universidad Nacional de Colombia, p. 657-691.

Le Maux L. \& L. Scialom (2013), « Antagonismos monetarios y creación de una banca central en los Estados Unidos (1865-1935) », in B. Théret (ed.), La Moneda develada por sus crisis, Bogotá, Universidad Nacional de Colombia, p. 127-162.

Loaiza G. (2011), Sociabilidad, religión y política en la definición de la nación. Colombia 1820-1886, Bogotá, Universidad Externado de Colombia.

Martínez A. (2006), El Lazareto de Boyacá: lepra, medicina, Iglesia y Estado. 1868-1916. Cómo Colombia fue convertida en la primera potencia leprosa del mundo y Boyacá, en una inmensa leprosería, Tunja, UPTC.

Noguera C. (1998), « La higiene como política. Barrios obreros y dispositivo higiénico: Bogotá y Medellín a comienzos del siglo xx ", Anuario Colombiano de Historia Social y de la Cultura, 25, p. $188-215$.

Obregón D. (2002), Batallas contra la lepra. Estado, Medicina y Ciencia en Colombia, Medellín, Banco de la República et EAFIT.

Ortega J. (1938), La Obra saleciana en los Lazaretos, Tomo I, Bogotá, Escuelas gráficas salecianas.

Peroni E. (2013, $2^{\mathrm{e}}$ ed.), El Puente de los suspiros, Bogotá, Grupo Zeta.

Pandya S. (2003), « The first international leprosy conference, Berlin, 1897: the politics of segregation ", História, Ciências, Saúde - Manguínbos, 10, supplement 1, p. 161-177.

Plata-Rueda C. (2007), La Voz del proscrito o la exclusión dese adentro: Lepra y Lazaretos en Colombia, Una interpretación antropológica, Tesis de Maestría en Antropología, Bogotá, Universidad Nacional de Colombia.

Rodríguez-Salazar O. (2016), « Soberanía y moneda en el siglo XIX en Colombia », in D. Arévalo (ed.), Soberanía política y regímenes monetarios, Bogotá, Universidad Nacional de Colombia, p. 15-112.

Rodríguez-Salazar O. (2011a), « Soberanía monetaria y ruptura de los lazos coloniales. Las Casas de Moneda en la Nueva Granada », in O. Rodríguez-Salazar \& D. Arévalo (eds), Propuestas y debates en Historia Económica, Bogotá, Universidad Nacional de Colombia, p. 221-287.

Rodríguez-Salazar O. (2011b), « Programas de investigación y políticas públicas en los sistemas de protección social ", in A. Hernández \& C. Rico (eds), Protección social en salud en América Latina y el Caribe, Bogotá, Universidad Javeriana, IDCR, Organización Panamericana de la Salud, p. 35-68.

Rodríguez-Salazar O. (2006), « Del patronato al aseguramiento en el sistema de protección social en Colombia: asistencia, identificación y legitimidad », in Y. Le Bonniec \& O. Rodríguez (eds), Crecimiento equidad y ciudadanía. Hacia un nuevo sistema de protección social, Bogotá, CID Universidad Nacional de Colombia, p. 197-221

Serna, Justo y Pons, Anaclet. 2002. « Formas de hacer microhistoria », Ágora Revista de Ciencias Sociales, 7 [En ligne: http://www.uv.es/ jserna/Fhm.htm]

Spufford P. (1991), Dinero y moneda en la Europa medieval, Barcelona, Critica. 
Théret B. (2013), « La moneda a través del prisma de sus crisis de ayer y de hoy », in B. Théret (ed.), La Moneda develada por sus crisis, Bogotá, Universidad Nacional de Colombia, p. 15-83.

Théret B. (2006), « Sistemas de protección social y representación política. Una perspectiva comparativa y estructural », in Y. Le Bonniec \& O. Rodríguez (eds), Crecimiento equidad y ciudadanía. Hacia un nuevo sistema de protección social, Bogotá: CID - Universidad Nacional de Colombia, p. 135-173.

\section{NOTES}

1. We refer here to one of the characteristics of Carlo Ginzburg's concept of micro-history (1994), where, as Serna and Pons (2002) point out, it is possible to approach "a subject of investigation which, for its strangeness, may reveal the negative or fragments of normal historical events or collective historical processes that are normal".

2. According to Gardeta (1999) the fear of contagion was found from the time of the Spanish colony. In the different legal regulations during the time span covered by this article, we often find references to demands, by the citizenry, that those with leprosy should not allowed to wander through the country's cities.

3. In the 1821 Constitution, to qualify as a citizen, one had to be a Colombian, an adult, literate, and with an assured income and not a livelihood which depended on another person, like that of a domestic servant or day-laborer.

4. For this sociologist, one of the central aspects, from the point of view of the construction of the State in the $19^{\text {th }}$ century, was the "question of the responsibility for faults: who was responsible? It was not by accident that the French philosophers and sociologists of the late $19^{\text {th }}$ century were concerned with the notion of responsibility: is responsibility a public or private matter? Does responsibility fall on individuals or it is up to public bodies to assume responsibilities? Finally, the public authorities became the ones who were responsible for the true causes, which were hidden under the apparent responsibilities of persons". (Bourdieu 2012, p. 572).

5. The period between 1886 and 1930 has been called the Conservative Republic, due to the political hegemony of that party. One of the characteristics of the period in the field of power was the alliance between big landowners, groups of exporters of agricultural products and the financial aristocracy.

6. According to González (2006, p. 74), in this period: "The idea that sovereignty resided in the Nation was restored, which was thought of as an organic, homogenous and corporative unit, set above particularisms and regionalisms". This alliance against radicalism was "to a very large extent the triumph of pro-Catholic forms of sociability, which the conservative elites in Bogotá were accustomed to share" (Loaiza 2011, p. 19). The Regeneration has been called a regime with a strong theocratic component, which sought to ensure public order and each individual's respect for his position in the social scale.

7. In his 1901 study of the geography of the disease, the French expert on leprosy, Don Sauton, stated that "Colombia is the region in the world most devastated by leprosy" and the Turkish doctor Démetrius Zambaco Pacha claimed in 1914 that $3 \%$ of the Colombian population suffered from leprosy. A kind of leprosy phobia seized the upper classes (Obregón 2002, p. 13). “In 1909 in Bogotá, Pablo García Medina, acting as Secretary of the Hygiene Board, published a Report on the Leper Colonies, where the official statistics compiled since 1905 were first published: there were 4,296 lepers, of which 3,031 were 
confined in the three leper colonies, that is, $72 \%$ " (Martínez 2006, p. 158). At the sixth Pan-American Congress, held in Montevideo in December, 1920, the Colombian representative, the same Pablo García Medina, tried to correct "the mistake about the exaggerated number of lepers in Colombia which still exists", putting the true figure at 6,500 (Coni 1921, p. 15).

8. The shares in that kind of bank were in the form of a diploma/share certificate: "on one side was a portrait of Father Unía or Dr. Medina, in the center, in big letters, it read "Bank of the Lepers; on the left: "Capital: the millions of the Divine Providence; on the right: "Interest: one percent; below that: "The Bank is placed under the guidance of the Divine Providence; it was founded in the first year of the $20^{\text {th }}$ century. Aim: to provide a home, clothing and food for the lepers of Colombia. It has branches in all the cities of the Republic". (Ortega 1938, p. 288). The confidence in this kind of bank rested on its invocation of the Divine Providence, which had a strong impact in a Catholic country which trusted the Church more than the sovereignty of the political power.

9. In 1903, the Boyacá Bank of the Leper Colonies was consolidated, on the basis of an association of priests, political leaders, businessmen and public employees. Its aim was to provide loans against a personal guarantee or mortgage, remittances and the sale of real estate, and bills of exchange (Acuña 2014).

10. Elena Peroni's novel El puente de los suspiros (The bridge of sighs, 2013) describes how the visitors to the leper colony had to be disinfected when they left that "city/jail". The Central Hygiene Board created by the Regeneration were abolished by the administrative reforms of the State in 1913, but it was reestablished under Law 84 of 1914. The Board was granted independence in the management of the leprosauria, a responsibility formerly granted to the Ministry of Government.

11. The Central Hygiene Board created by the Regeneration had been abolished by the administrative reforms of the State in 1913, but it was reestablished under Law 84 of 1914. The Board was granted independence in the management of the leprosauria, a responsibility formerly granted to the Ministry of Government.

12. Despite the different reforms, structural changes in monetary exchange only came about after 1923, with the creation of the Banco de la República, which was to serve as a central bank.

13. Since 1913, practically all of the legislative sessions had presented more than one bill for that purpose.

14. In 1915 , to counteract the fall in public revenues, a tax on consumption was established (which accounted for the equivalent of $20 \%$ of the fiscal deficit), taxes on stamps and sheets of paper with the State seal were increased and the funds which the Conversion Board had (meant for the exchange of paper money) were deposited in the "common funds" of the General Treasury.

15. Since 1913, practically all of the legislative sessions had presented more than one bill for that purpose. In the 1917 sessions of the Congress three bills were presented: two for a bank of emission, proposed by the Treasury Ministry and another by the Council of State. The resolution of this subject had to wait until 1923, when the Banco de la República was founded as a central bank.

16. In general, the ration was a term that allowed expressing a daily food allowance, for example in the case of hacienda workers, prisoners in prisons or hospitalized patients. These rations could either be delivered in goods and services or in a monetary equivalent.

17. Compliance with the norms of confinement varied in different places and at different times. In the early decades of the $20^{\text {th }}$ century enforcement of the norms was especially strict in the Leper Colony of Contratación, which had to do with the fact that its geographical isolation made it very difficult to supply the colony with goods and obtain incomes beyond the ration. In Agua de Dios, which was more accessible and closer to dynamic markets, there were more healthy persons living in the colony. 
18. "The neutrality of currency is a sine qua non condition of the existence of pure economics. By nature, it is always in equilibrium" (Aglietta 2016, p. 40). The controversy about normative economics always extends to the supposed neutrality of currency and its detachment from political aspects. In that regard, the current trend of "regarding" currency as a variable which is "exogenous" to political aspects does not have much meaning. Insofar as it is supplied with information about the state of the economy deriving from the payments it makes and thus has information which the other agents in the economy lack, the work of the central bank invalidates the hypothesis of neutrality; since on the basis of this information the central bank may implement monetary policies at its discretion which affect given sectors of the economy, whether it favors or negatively affects them (Aglietta 2016).

19. The political centralization sponsored by the Regeneration led to the establishment of the Central Hygiene Board, and Law 104 of 1890 which authorized obligatory isolation, which was reaffirmed by legislative decree 14 of 1905 and Decree 1024 of 1905 . The Board was a dependency of the Ministry of Government. In 1918, in addition to changing its name to the National Directorate of Hygiene, this board became a dependency of the Ministry of Public Education. In 1931, the Directorate became known as the National Department of Hygiene and Public Care and was transferred to the Ministry of Government, and later, in 1938, to the Ministry of Labor and Social Care.

\section{ABSTRACTS}

This article is an account of the experience of the policy for the fight against leprosy developed in Colombia between 1890 and 1930, which combined the obligatory confinement of the diseased with the existence of a special currency for leper colonies. The purpose of analyzing that experience is to probe the links between that currency and social protection, as well as to discuss the theoretical elements which allow us to analyze that link in societies which have not attained an extension of the salaried relationship.

Dans cet article, nous présentons la politique de lutte contre la lèpre menée en Colombie entre 1890 et 1930, qui combinait le confinement obligatoire des malades avec l'existence d'une monnaie spéciale pour les colonies de lépreux. Le but de l'analyse de cette expérience est de sonder les liens entre cette monnaie et la protection sociale, ainsi que de discuter les éléments théoriques qui permettent d'analyser ce lien dans les sociétés qui n'ont pas atteint une extension de la relation salariée.

\section{INDEX}

Mots-clés: monnaie, lèpre, protection sociale

Keywords: currency, leprosy, social protection

JEL Code E42 - Monetary Systems • Standards • Regimes • Government and the Monetary System - Payment Systems, I18 - Government Policy • Regulation • Public Health, I30 - General 


\section{AUTHORS}

\section{OSCAR RODRÍGUEZ SALAZAR}

Universidad Nacional de Colombia, Grupo de Protección Social

\section{DÉCSI ARÉVALO HERNÁNDEZ}

Universidad de Los Andes, Grupo de Protección Social 